\title{
A note on regulatory responses to COVID-19 pandemic: Balancing banks' solvency and contribution to recovery
}

\author{
Mohammad Bitar ${ }^{1 \dagger}$, Amine Tarazi ${ }^{2,3}$ \\ ${ }^{1}$ Nottingham University Business School, University of Nottingham, Jubilee Campus, Nottingham NG8 1BB, United \\ Kingdom. \\ ${ }^{2}$ Université de Limoges, LAPE, 5 rue Félix Eboué, 87031 Limoges Cedex, France; ${ }^{3}$ Institut Universitaire de France \\ (IUF), 1 rue Descartes, 75231 Paris Cedex 05, France.
}

\begin{abstract}
.
We see spikes in unemployment rates and turbulence in the securities markets during the COVID19 pandemic. Governments are responding with aggressive monetary expansions and large-scale economic relief plans. We discuss the implications on banks and the economy of prudential regulatory intervention to soften the treatment of non-performing loans and ease bank capital buffers. We apply these easing measures on a sample of Globally Systemically Important Banks (G-SIBs) and show that these banks can play a constructive role in sustaining economic growth during the COVID-19 pandemic. However, softening the treatment of non-performing loans along with easing capital buffers should not undermine banks' solvency in the recovery period. Banks should maintain usable buffer in the medium-term horizon to absorb future losses, as the effect of COVID-19 on the economy might take time to fully materialise.
\end{abstract}

JEL Classification: G18, G21, G28

Keywords: COVID-19, non-performing loans, capital buffers, solvency, G-SIBs

†Corresponding author. Email addresses: mohammad.bitar@nottingham.ac.uk; amine.tarazi@unilim.fr. 


\section{Introduction}

In December 2019, The Chinese Center for Disease Control and Prevention (CCDC) informed the World Health Organization (WHO) of unknown cases of pneumonia that took place in the city of Wuhan, Hubei province of China (WHO, 2020). The novel virus belongs to a large family of coronaviruses such as the Severe Acute Respiratory Syndrome (SARS) and the Middle East Respiratory Syndrome (MERS-CoV). Coronavirus is a respiratory virus; it is contagious and can spread through droplets generated when an infected person coughs or sneezes. The WHO characterized the disease as a pandemic on March 11, 2020 (WHO, 2020), and proposed an official name, COVID-19, an acronym that stands for coronavirus disease 2019. At the time of writing this paper, the pandemic is still ongoing and the number of COVID-19 cases have reached 7.34 million globally while the death toll has reached 416,430 people. ${ }^{1}$ Fig. 1 compares the number of COVID-19 confirmed cases and deaths between several developed countries and China. While the number of confirmed cases and deaths continue to increase rapidly in the US (Fig. 1B), EU countries along with the UK, Canada, and Japan have started to flatten their curve (Fig. 1A). Finally, China seems to have managed to flatten its curve as early as the end of March 2020 (Fig. 1C).

\section{INSERT FIGURE [1] AROUND HERE}

Although the rapid spread of COVID-19 have taken both governments and health officials by surprise, governments have mainly responded by trying to contain, delay, and mitigate the effect of the disease on their national health system. In general, the "golden rule", implemented by government officials, requires shutting down schools and workplaces, imposing travel restrictions, staying home orders and employing social distancing measures, along with various economic relief plans, aggressive monetary expansion, and bank prudential regulatory measures. The purpose of these actions is to reassure investors and the public, and alleviate the negative effects of COVID-19 on economic growth and the soundness of the financial system. These relief plans are similar to the ones implemented during the 2007/2009 financial crisis; yet, their scale is massive and covers all economic sectors. In addition, these plans are characterised as short-term and only structured to sustain minimal economic activities for a few months.

Against this background, this paper considers three questions. First, we question how the impact of COVID-19 on the economy and the securities markets affects bank credit risk. Second,

\footnotetext{
${ }^{1}$ Ourwroldindata.org, https://ourworldindata.org/grapher/total-deaths-and-cases-covid-19. Last accessed on June 11, 2020 .
} 
what are prudential regulators doing so far in responding to the pandemic? Finally, what are the potential implications of prudential regulatory intervention on bank solvency in the recovery period? To address these questions, we follow three steps. First, we explore how the impact of COVID-19 on the level of employment, interest rates, and the securities markets affects bank credit risk. Second, we compare prudential regulatory responses to lessen the growing pressure on the economy and the financial sector. We focus on two common aspects used in the relief packages undertaken in the United States, the EU, the UK, and Canada: i) the easing of bank capital buffers and ii) the economic relief plans. Finally, we consider a sample of Globally Systemically Important Banks (G-SIBs) to discuss the implications of softening the treatment of non-performing loans (NPLs) and easing capital buffers on credit supply and bank solvency.

Recent economic and finance literature is oblivion about the influence of pandemics and epidemics on economic growth and financing decisions. While the WHO warned in a recent report $^{2}$ that the world is in an imminent danger of a global pandemic (WHO, 2019), little or no actions have been undertaken by researchers and policy makers to study the potential effect of diseases on economic growth. One notable study is Fan et al. (2018), who estimates that the expected annual losses from pandemic events is approximately $\$ 500$ billion, or 0.6 percent of global income, a sum that now appears to be greatly underestimated. Recent figures show a significant effect of COVID-19 on global economy growth. From job loss to the growing uncertainty and the volatility of the securities markets, the World Economic Outlook (WEO) report, recently published by IMF, shows that global economic growth is estimated at -3 percent in 2020. Advanced countries such as the US, the EU, the UK, and Canada's economic growth is estimated at $-6 \%$ on average. The effect of the pandemic is estimated to be lower in emerging markets and developing economies. While the WEO is projecting a $-1 \%$ economic growth for emerging and developing economies, China's economic growth remains above zero and estimated at $1 \%$ for 2020 .

Several recent studies focus on the impact of the COVID-19 on stock and cryptocurrency markets. For instance, Onali (2020) finds that US stock market returns are negatively affected by the COVID-19 reported deaths in France and Italy but not by the number of cases and deaths in the US itself. Corbet et al. (2020) and Conlon and McGee (2020) conclude that cryptocurrency markets do not act as hedges, or a safe haven for investors during the COVID-19 outbreak. Other studies investigate herding in the stock and the cryptocurrency markets. While, Yarovaya (2020)

\footnotetext{
${ }^{2}$ Global Preparedness Monitoring Board report (2019).
} 
finds no evidence of increased herding in the cryptocurrency markets during the COVID-19 period, Kizys et al. (2020) show that regulatory restrictions implemented by regulators reduce investor herding in international stock markets during the pandemic. Thus, this paper aims to complement the embryonic literature on COVID-19 by discussing the actions undertaken by governments and bank prudential regulators to lessen the economic fallout from the pandemic and maintain the supply of credit. Specifically, we discuss the implications on banks and the economy of softening the treatment of NPLs and easing capital buffers. In addition, we apply these easing measures on a sample of G-SIBs and show that these banks may play a constructive role in sustaining economic growth during the COVID-19 pandemic. However, it might be counterproductive if - because of depleted buffers combined with higher credit risk - economic and financial distress thwarts the recovery from the COVID-19 shock that was originally nonfinancial.

The rest of the paper is organized as follows. Section 2 explores how the impact of COVID-19 on the economy and the securities markets affects bank credit risk. Section 3 briefly reviews the Basel III capital reforms and provides descriptive statistics on G-SIBs compliance with capital requirements. Section 4 discusses the implications of prudential regulatory intervention adopted by four governments in response to the COVID-19 pandemic. Section 5 concludes.

\section{The effects of COVID-19 on the economy, the securities markets, and bank credit risk}

We provide key figures on the direct and immediate effect of COVID-19 on employment, monetary policy, the financial markets, and bank credit risk. Fig. 2A shows that the number of Americans filing for unemployment benefit claims has hit a record high of more than 20.161 million, in March 2020, compared to only 862,000, recorded in March 2019. In addition, the American legislator approved a $\$ 300$ billion in direct payment to households, providing $\$ 1,200$ to adults and \$500 per child. Similarly, the Canadian government has created the Canada Emergency Response Benefit (CERB) to support independent, seasonal, and part-time workers who cannot access the employment benefit claims. CERB provides a \$2000CAD in a direct payment for a period of 4 months starting March 15, 2020. By the end of the first week of June 2020, more than 15.44 million Canadians have applied for CERB aid to replace incomes lost due to COVID-19. ${ }^{3}$ In addition, depending on how long the lockdown policies may continue, workers who are expecting to resume their jobs, may end up in losing their jobs permanently due

\footnotetext{
${ }^{3}$ Statistics Canada, https://www.canada.ca/en/services/benefits/ei/claims-report.html. Last accessed on June 11, 2020
} 
to many small and medium enterprises going bankrupt. This situation might increase bank exposure to credit risk if borrowers' income level is affected in the medium-term.

One early response to the COVID-19 pandemic was the Central Banks lowering interest rates. Fig. 2B shows two groups of countries: 1) Countries with relatively high interest rates before the COVID-19 pandemic such as the United States and Canada, and 2) countries with relatively low interest rates before the COVID-19 pandemic such as the European Union countries. For example, the Federal Reserve cut the Federal Fund rate (FedFR) from 2.75\% in February 2020 to $0.25 \%$ in March/April 2020. The Bank of Canada has also cut the Target Rate (BoCTR) from $1.75 \%$ to $0.25 \%$ in March 2020. However, for some countries such as France, Italy, and Germany, the European Central Bank's refinancing rate (ECBRR) was already 0\%. Thus, lowering interest rates may have a very limited and nonhomogeneous effect on stimulating economic growth, given the prevailing low interest rates in some countries compared to other countries. Nevertheless, Central Banks have combined reduced interest rates with some quantitative measures such as the purchase of securities in order to increase monetary supply and ease the pressure on various economic sectors.

\section{INSERT FIGURE [2] AROUND HERE}

Regarding the effect of COVID-19 on securities and commodities markets, the 2020 first quarter reported the most significant decline in the stock and the bond market indexes since the Great Depression, exacerbated by a negative oil price. Fig. 3A shows that the economic freeze on production in major industrial countries such as the US and China as well as the slow response and the inability of OPEC coalition to reach a proper agreement on how to react to the weak oil demand has led to the rapid collapse in oil prices. As for the securities markets, Fig. 3B shows that since March 9, 2020, equity prices on major stock indexes such as the Dow Jones Industrial Average (DOW), the Standard and Poor's 500 (SP500), and the NASDAQ composite (NASDAQ) have sharply fallen but started to very quickly recover as of the first week of April 2020. Bond markets have also been sharply affected; Fig. 3C shows that the 10 -year bond yields (10UST) in the United States have tumbled to reach a record low of 0.54\% in March 9, 2020. In addition, the negative effect of COVID-19 on the economy has led the securities markets to price assets using the worst-case scenario, reflected in a sharp increase in the stock markets' volatility index (VIX) as shown in Fig. 3D.

INSERT FIGURE [3] AROUND HERE 
While the above figures are showing large uncertainty about the future of employment and the securities markets, maintaining a status quo in the medium-term may lead to a large increase in borrowers' default and thus an increase in bank credit risk. A simple calculation gives a minimal idea of this. Table 1 shows the aggregated assets of the 33 G-SIBs operating in 12 countries at the end of 2017. We refer to the Financial Stability Board (FSB) list of G-SIBs and collect the data on bank regulatory capital from the Orbis BankFocus database. We focus on GSIBs because of their scale and the degree of their importance and interconnectedness within the global and the domestic financial markets. They are important since their failure may affect the stability of the financial system as a whole and the development of the global economy. Total assets amount to $\$ 55.2$ trillion, of which $\$ 24.1$ trillion are loans ${ }^{4}$ to the economy and $\$ 12.5$ trillion are securities. Since G-SIBs capital ${ }^{5}$ amounts to $\$ 4$ trillion, it would only take $16.6 \%$ $(24.1 * 16.6 \%=4)$ of the G-SIBs loans not being reimbursed to wipe out their entire capital. These numbers do not even account for the price drop in securities markets (as shown in Fig. 3), which mechanically shrinks the value of G-SIBs trading portfolio in securities. Due to accounting standards, securities are recorded at market value (trading book) and changes in market conditions are immediately reflected in the bank balance sheet.

\section{INSERT TABLE [1] AROUND HERE}

To examine whether the rate of $16.6 \%$ credit default is possible in the recovery period, we retrieve data on bank credit risk using the same sample reported above. We use two bank-level measures of credit risk, i.e. the impaired loans to gross loans ratio and the bank type of riskweighted assets (i.e. credit risk, market risk, and operational risk) divided by total risk-weighted assets ratio, and one country-level aggregated measure of credit risk, i.e. the non-performing loans to gross loans ratio. Data on bank-level credit risk is collected from Orbis BankFocus while data on country-level credit risk is collected from the International Monetary Fund website. Bank-level data covers 33 G-SIBs located in 12 countries and covering the preCOVID-19 period, spanning from 2011 to 2019. Fig. 4A shows that the ratio of impaired loans to gross loans had fallen significantly between 2013 and 2019, from an average of $3.38 \%$ to $1.85 \%$. The ratio of non-performing loans to gross loans ratio is showing a very similar pattern but with large disparities between countries. Fig. 4B shows that Italy had a non-performing loans ratio of $18.1 \%$ in 2015 , higher than the $16.6 \%$ figure presented above, and was still significantly above the G-SIBs countries' average in the preCOVID-19 period estimated at 3.44\%. In addition, Fig.

\footnotetext{
${ }^{4} 30 \%$ of G-SIBs loans are residential mortgages, and loans and leases to corporate enterprises.

${ }^{5}$ The ratio of total capital to total assets (or the unweighted capital ratio) represents $7.23 \%$ of bank total assets.
} 
4.C indicates that in the preCOVID-19 period, bank exposure to credit risk dominated exposures to market risk and operational risk, and accounts for $78.42 \%$ of G-SIBs risk-weighted assets, on average. Of course, these figures do not take into account the decrease in the value of G-SIBs investments in the securities markets (trading portfolio). Recall that G-SIBs trading portfolio accounts for $23.2 \%$ of their total assets. Consequently, it is possible that the capital of some banks will be exhausted if credit risk screening measures are relaxed and bank capital buffers are depleted, which may lead to an insolvency crisis in the recovery period. In the next sections, we review bank capital requirements in the preCOVID-19 period and discuss the implications on the economy for four cases of prudential regulatory intervention to ease capital buffers.

\section{INSERT FIGURE [4] AROUND HERE}

\section{Bank capital requirements in the pre COVID-19 period}

To understand how banking institutions may be in a better position in helping the economy to absorb the impact of the COVID-19 pandemic compared to their position during the 2007/2009 financial crisis, we first review the Basel III capital reforms and examine bank compliance with regulatory capital ratios using a sample of G-SIBs for the preCOVID-19 period.

Twelve years after the 2008 financial crisis, regulatory authorities have succeeded in significantly increasing bank regulatory capital ratios. Since the introduction of the Basel III capital reforms in 2010, banks - in particular G-SIBs - have been required to hold higher capital of good quality in the form of Common Equity Tier 1 (CET1). While the figures we present in section two show that the global economy is on track for its sharpest recession since the Great Depression, banking institutions, especially G-SIBs, continue to provide lending services to businesses and households. This continuous effort to save the global economy from collapsing highlights how Central Banks and governments expect that the largest banks will play a more constructive role than the role they played during the 2007/2009 financial crisis. These banks were widely blamed for their lack of support during the economic downturn that has followed.

Basel III capital reforms require G-SIBs to increase their capital of good quality and build up several additional capital buffers to prevent potential negative externalities related to bank systemic failure. The cornerstone of Basel III capital requirements is the common equity Tier 1 (CET1). This core element represents bank capital of good quality and mainly includes common shares and retained earnings. Regulatory authorities require G-SIBs to hold a mandatory minimum CET 1 of $4.5 \%$ of risk-weighted assets. Additional Tier 1 capital complements CET1 and mainly includes instruments issued by the bank that meet the criteria for inclusion in 
additional Tier 1 but not included in CET1. Additional Tier 1 capital should not exceed 1.5\% of risk-weighted assets. Both CET1 and additional Tier 1 constitute bank Tier 1 capital (T1R) and has to be at least $6 \%$ of risk-weighted assets. Tier 2 capital (T2R) complements Tier 1 capital and consists of various subordinated debts and loan loss provisions. Minimum Tier 2 capital is at least $2 \%$ of risk-weighted assets. Both Tier 1 capital and Tier 2 capital constitutes bank the Capital Adequacy Ratio (CAR). Overall, banks comply with the Basel III capital reforms when they maintain a minimum capital adequacy ratio of $8 \%$ of risk-weighted assets. ${ }^{6}$

Additionally, Basel III capital reforms require banks to build-up two additional capital buffers, the capital conservation buffer and the countercyclical buffer. The Capital Conservation Buffer (CCB) equals to $2.5 \%$ of bank risk-weighted assets; it consists of CET1 with a main objective to conserve bank capital of good quality. Regulators may impose limits on dividend and bonus payments if banks fail to maintain their CCB at $2.5 \%$. The Countercyclical Buffer (CyB) varies between 0 and $2.5 \%$ of bank risk-weighted assets and should be met using CET1. CyB aims to reduce counter pro-cyclicality in the financial system. Banks can accumulate their CyBs in periods of economic growth and use them in periods of economic distress. While the CCB level is fixed at $2.5 \%$, the designated national authorities adjust the CyB level periodically. A bank may be subject to restrictions on distribution of earnings if it fails to meet the CyB requirements. Finally, the Basel III capital reforms responded to the "too-big-to-fail" problem by requiring G-SIBs to build up an additional capital buffer - known as G-SIBs capital surcharge that varies between 0 and $3.5 \%{ }^{7}$ of risk-weighted assets and should be met using CET1.

We examine bank compliance with the Basel III regulatory capital reforms using a sample of 33 G-SIBs operating in 12 countries and covering the preCOVID-19 period, spanning from 2011 to 2019. The number of available observations on the components of CAR varies between years with 2017 reporting the highest number of available observations across the sample period. Thus, we use 2017 as a base year to compute the CCB, CyB, and the G-SIBs capital surcharge.

\footnotetext{
${ }^{6}$ While the standardised minimum capital adequacy ratio is $8 \%$, many national authorities require their banks to maintain a capital adequacy ratio well above the minimum regulatory capital ratio of $8 \%$. For instance, several developing and emerging countries have minimum capital adequacy ratios that vary between $10 \%$ and $16 \%$ of riskweighted assets. As for developed countries - a headquarter to most of G-SIBs - local authorities maintain the same standardised level of minimum capital adequacy ratio required by the Basel III's capital requirements, which is $8 \%$ of risk-weighted assets.

${ }^{7}$ G-SIBs capital surcharge varies in accordance with how systemically important they are. The Financial Stability Board (FSB) have allocated G-SIBs into 5 buckets corresponding to the required levels of capital surcharges. For instance, bucket 1 represents G-SIBs at the lower side of the distribution and allocates 1\% of additional CET1 as a percentage of risk-weighted assets to be included in the bank capital surcharges. Bucket 5 represents G-SIBs at the upper side of the distribution and allocates $3.5 \%$ of additional CET1 as a percentage of risk-weighted assets to be included in the bank capital surcharge.
} 
Table 2 Panel A and Fig. 4D show that while the minimum CAR is $8 \%$, G-SIBs prefer to hold CARs well above the minimum standardized level. However, due to the gradual implementation of the capital reforms across countries, the average CAR for G-SIBs varies significantly. CAR increased from $14.23 \%$ in 2011 to $17.41 \%$ in 2019 (Fig. 4D), with the lowest value around 13.91\% in Spain and the highest value around 19.61\% in Sweden (Table 2, Panel A). The statistics suggest that G-SIBs in Northern European countries along with UK, and American banks are highly capitalized compared to their Southern European and Chinese counterparts. Fig. 4D also shows that more than $66 \%$ of CAR is core capital in the form of CET1. Furthermore, Panel A shows that national regulatory authorities require banks to maintain their CCB at $2.5 \%$ of risk-weighted assets. The level of banks' CyBs, however, varies substantially across jurisdictions. While most G-SIBs located in the EU have maintained their CyB near or at $0 \%$, other countries such as Canada, Sweden, and China have chosen to maintain their CyB at $2.5 \%$ of risk-weighted assets.

Table 1 Panel B shows that G-SIBs are well capitalized; they maintain around $\$ 3.508$ trillion of total capital out of which $\$ 2.727$ trillion is categorized under CET1 or capital of good quality. Panel B also shows that G-SIBs have almost accumulated \$534 billion under CCB in 2017. Countries such China and the United States have accumulated \$206 billion and \$158 billion, respectively, thus representing 68.2 percent of the total value of CCB for G-SIBs. As for the CyB, G-SIBs have approximately accumulated $\$ 248$ billion, largely dominated by Chinese banks with \$206 billion. Finally, Panel B shows that the accumulated capital surcharge has reached \$300.7 billion in 2017 and expected to be much higher in 2018 and 2019. Once again, American and Chinese banks hold $\$ 112$ billion and $\$ 104$ billion, respectively, representing $87.1 \%$ of the total value of capital surcharge for G-SIBs.

\section{INSERT TABLE [2] AROUND HERE}

Overall, the numbers indicate a large cross-country variation in G-SIBs capital buffers, where G-SIBs in the United States and China dominate their counterparts in other countries. Capital buffers are important tools available to banks in times of economic downturns such as the COVID-19 period; they can be used in the short-term horizon to support the continuous provision of credit to households and businesses instead of using taxpayers' resources. Nevertheless, the use of these buffers along with a more lenient treatment of non-performing loans (NPLs) should not undermine banks' solvency in the future. In the next section, we review 
four measures undertaken by prudential regulators and governments to ease bank capital buffers during the COVID-19 pandemic.

\section{Governments' responses to COVID-19 pandemic: Easing capital buffers and lenient treatment of NPLs}

Now, we discuss the implications on the economy for four cases of prudential regulatory intervention to ease capital buffers in the US, the EU, the UK, and Canada. We also review the measures undertaken by regulators allowing for a more lenient treatment of NPLs. Prudential regulators can ease capital buffers in three ways. First, they can partially or totally remove the requirements on capital buffers such as in the UK and Canada. Second, they can publicly or privately encourage temporary ease of capital requirements such as in the EU. Finally, they can de-link the use of capital buffers from dividend payments such as in the US. We discuss each of these four cases below.

\section{Case 1: The US response to COVID-19 pandemic-delinking CCB from dividend payments}

Under the Fed rule, if the largest American banks' CCB falls below 2.5\% of risk-weighted assets plus the required CyB and the G-SIBs capital surcharge, the bank becomes subject to stringent limitations on capital distributions and discretionary bonus payments. These distributions are calculated as a percentage of eligible retained income. Eligible retained income is defined as the average net income for the four calendar quarters preceding the current calendar quarter, net of any distributions. On March 20, 2020, the Fed approved a new revised (interim) rule allowing banks to more gradually limit distributions in the COVID-19 period. The new rule defines eligible retained income as the average of net income for the four quarters preceding the current calendar quarter. This revision will allow banks to build-up their CCB more easily since they no longer need to deduct distributions of previous years from their net income. The revision will also reduce stringent limitations on bank capital distributions and discretionary bonus payments by allowing it to be more gradual.

To examine how the distribution limitations under the new interim rule can be more gradual, we collect quarterly data on net income and retained earnings for five G-SIBs in the United States from the CRSP/Compustat merged database. ${ }^{8}$ The data shows that these banks had $\$ 22.86$ billion, on average of net income for quarter 3, 2018 to quarter 3, 2019 period. For quarter 4,2019 , these banks had $\$ 583.31$ billion available for distribution ( $\$ 562.92$ billion prior

\footnotetext{
${ }^{8}$ Out of the eight G-SIBs reported in Table 1, data on net income and retained earnings is only reported for five banks.
} 
quarter retained earnings and 20.39 billion current quarter net income). ${ }^{9} \mathrm{We}$ assume that the GSIBs maintain adequate levels of CyBs and capital surcharges. We also assume that banks distribute $75 \%$ of their net income at each quarter. Fig. 5 compares the maximum payout amounts under the new interim rule and the Basel III rule. The graph clearly shows that under the new interim rule, the maximum distribution allowable in quarter 4, 2019 declines more gradually, whereas the previous Basel III rule has a more significant cliff at $2.5 \%$. This revision provides banks with stronger incentives to continue their supply of credit and support economic growth in the short-term horizon.

\section{INSERT FIGURE [5] AROUND HERE}

\section{Case 2: The EU response to COVID-19 pandemic - temporary capital relief}

The European Central Bank (ECB) requires banks in member states to follow a more stringent definition of capital compared to banks in the United States and Canada. ECB defines minimum capital requirements' ratio as the sum of Pillar 1 capital and Pillar 2 capital (excluding Pillar 2 Guidance, explained below). In addition, banks are required to add up several capital buffers, including the $\mathrm{CCB}$, the $\mathrm{CyB}$, and the G-SIBs capital surcharge. Pillar 1 capital is the sum of Tier 1 capital and Tier 2 capital. Pillar 2 capital consists of two parts. Pillar 2 Requirements (P2R), which includes risks that are not underestimated or not sufficiently covered by Pillar 1. Pillar 2 Guidance (P2G), which specifies to each bank the adequate level of capital to be maintained in stress situations. The level of adequate capital is calculated based on factors related to adverse scenarios in the ECB's supervisory stress tests. If a bank fails to meet the ECB minimum capital requirements, restrictions may be imposed on the distributions of dividends and bonuses. On March 12, 2020, the ECB announced that banks could temporarily operate below their P2G, the CCB, the CyB, and the G-SIBs capital surcharge. In addition, the ECB will allow banks to partially use additional Tier 1 or Tier 2 instruments that do not qualify as CET1 to meet P2R.

Recall that Table 2 Panel A shows large differences between EU countries capital buffers' requirements. While banks maintain $\mathrm{CCBs}$ at $2.5 \%$ of risk-weighted assets in all countries, the level of CyB varies between 0\%, in Germany, Italy, Netherlands and Spain, 0.5\% in France, and 2.5\% in Sweden. For example, Panel B shows that in 2017 the four G-SIBs in France hold more than $\$ 95$ billion in their CCB, CyB, and G-SIBs capital buffers compared to $\$ 9$ billion build-up by the one Swedish G-SIB. These differences indicate that releasing buffers, in particular the

\footnotetext{
${ }^{9}$ We focus on quarter 3, 2018 to quarter 4, 2019 period because data is not available on quarter 1, 2020.
} 
$\mathrm{CyB}$, may have a very limited and nonhomogeneous effect on supporting banks and stimulating economic activity, given the prevailing low and sometimes non-existent $\mathrm{CyBs}$ in some EU countries compared to other countries in the preCOVID-19 period. The ECB estimates that the release of the $\mathrm{P} 2 \mathrm{G}$ as well as the less stringent requirements regarding additional Tier 1 capital and Tier 2 capital instruments will allow banks to use around $€ 120$ billion of additional CET1 capital to maintain economic activities in the short-term horizon.

Case 3: The UK response to COVID-19 pandemic - total release of CyB

In early January 2020, the UK CyB was at $1 \%$ of risk-weighted assets and has been due to reach $2 \%$ by December 2020. However, on March 11, 2020, the Financial Policy Committee (FPC) reduced the $\mathrm{CyB}$ to $0 \%$ to provide additional support to banks in supplying the economy. The FPC decision will be maintained for at least 12 months and any subsequent increase would not take effect until March 2023 at the earliest.

Based on the available data and our calculations, Table 2 Panel B shows that the four GSIBs in the UK have more than $\$ 18.45$ billion in their CyB in 2017 . With the total release of the $\mathrm{CyB}$, businesses and households should be able to rely on banks to meet their needs for financing to maintain their activities during the COVID-19 distress period. According to the FPC, the release of the CyB will enable all UK banks to provide $£ 190$ billion in additional lending to the economy.

Case 4: The Canadian response to COVID-19 pandemic - partial relief of CyB

In Canada, the CyB was at $2.25 \%$ of risk-weighted assets to be effective as at April 30, 2020. However, on March 13, 2020, the Office of the Superintendent of Financial Institutions (OSFI) reduced the CyB to $1 \%$ in response to the current challenges imposed by COVID19. According to the OSFI, releasing the CyB aims to improve the resiliency of the Canadian financial systems and boost lending and economic growth. OSFI committed that any further increase in the buffer will not be made for at least 18 months from the above date.

Based on the available data and our calculations, Table 2 Panel B shows that the largest Canadian bank in 2016, i.e. the Royal Bank of Canada (RBC), had more than $\$ 7.55$ billion in its CyB. With the COVID19 CyB adjustment, RBC can have a $\$ 4.19$ billion of additional lending capacity to the Canadian economy. However, 2016 is the latest year of available data for RBC; we expect that the actual CyB value to be higher in 2019. According to the OSFI, the release of 
the CyB will enable Canadian banks to provide \$300CAD billion in additional lending to the economy in the short-term horizon.

Finally, prudential regulators have taken complementary actions to further increase bank capacity to supply credit. In addition to easing capital buffers, regulators have allowed for a more lenient treatment of NPLs, which would help in reducing the erosion in bank regulatory capital that results from increased provisioning for expected credit losses. Prudential regulators have also provided guidance on how banks can reduce their risk-weighted assets by taking into account government emergency support to the real economy, notably government guarantees. By slowing down the decrease in banks' regulatory capital ratios, these complementary actions can reduce the rate at which banks can draw down their CCBs and CyBs, thus acknowledging losses and allowing a given amount of equity capital to support a larger credit supply. Table 3 provides a brief review of prudential regulatory measures taken by governments in the US, the EU, the UK, and Canada along with the general economic relief plans enacted to alleviate tensions for all economic sectors.

\section{INSERT TABLE [3] AROUND HERE}

Overall, the easing of capital buffers along with the lenient treatment of NPLs can be effective if included with a general strategic plan that evolves depending on the economic impact of COVID-19 pandemic. This plan should have a medium-term horizon and combine transparency and effective market discipline. Stimulating credit supply by allowing banks to use their capital buffers may be short-lived if banks take on more risk with no buffers. In addition, more lenient treatments of NPLs along with the government guarantees to reduce risk-weighted assets should not compromise the "more skin in the game" policy. Such a policy is important to protect bank solvency and increase lenders' ability to discriminate between good and bad credit. Sustaining economic activities during the COVID-19 is important; however, the use of capital buffers along with the complementary actions should not undermine banks' solvency over the medium-term. Otherwise, the COVID-19 economic shock may be replaced with a long recession and severe financial crisis in the recovery period.

\section{Conclusion}

How does the impact of COVID19 on the economy and the securities markets affect bank credit risk? What are the governments and the prudential regulators doing so far in responding to the pandemic? We show that the securities markets are responding to the COVI19 with panic 
trading and worrying volatility. Along with a reduced oil price, countries have been reacting by implementing various government-led economic relief plans. These plans have a massive scale and cover all economic sectors; however, they are characterized as short-term and only structured to sustain minimal economic activities for a few months.

Focusing on the prudential regulatory actions taken by governments to ease bank capital requirements, we document that banks should be able to play a constructive role in maintaining economic activities during the COVID-19 pandemic. Using a sample of Globally Systemically Important Banks (G-SIBs), we document that these banks are well capitalized in the preCOVID19 period and that various measures, although very different across countries, have been taken to ease capital requirements. While EU countries deferred the application of more stringent capital rules, countries such as the US, the UK, and Canada are temporary relaxing their countercyclical buffers. We hence argue that such measures may not have the same intended effect of stimulating economic growth everywhere. Nevertheless, depending on the level of additional capital buffers maintained in the preCOVID-19 pandemic, releasing these buffers may provide G-SIBs with flexibility in their lending decisions. However, the use of capital buffers along with the complementary actions, such as softening the treatment of non-performing loans (NPLs), could undermine banks' solvency over the medium-term. Therefore, the COVID-19 economic shock could still possibly lead to a long recession and a severe financial crisis if regulators do not carefully adjust their action depending on short-run developments.

At the time of writing this paper, governments and regulators are at the limits of what they can do in terms of recovery. Enacting economic relief plans are welcomed in the short-term but cannot continue indefinitely with no real changes in community behaviour or a medical breakthrough. As we move ahead, we need to fundamentally rethink our societal behaviour and try to understand the "new normal" in our economic activities and financial decisions. It would be hard to believe that we can just "switch on" the economy again and go back to the preCOVID-19 economic conditions; rather, combating the virus requires more strategic actions from governments than just enacting short-term relief packages. These actions should have a medium-term horizon and combine transparency and effective market discipline without compromising prudential regulation. 


\section{References}

Bank of England (BoE). (2020). BoE measures to respond to the economic shock from Covid-19.

Bank of England (BoE). (2020). Financial policy summary and record.

Conlon, T., and McGee, R. (2020). Safe Haven or Risky Hazard? Bitcoin during the COVID-19 Bear Market. Available at SSRN 3560361.

Corbet, S., Larkin, C., Lucey, B., Meegaan, A., and Yarovaya, L. (2019). Cryptocurrency reaction to FOMC announcements: Evidence of heterogeneity based on Blockchain stack position. Journal of Financial Stability 46, in press, https://doi.org/10.1016/j.jfs.2019.100706.

Corbet, S., Larkin, C.J., and Lucey, B.M. (2020). The contagion effects of the covid-19 pandemic: Evidence from gold and cryptocurrencies. Available at SSRN 3564443.

European Central Bank (ECB). (2020). ECB Banking Supervision provides temporary capital and operational relief in reaction to coronavirus.

European Central Bank (ECB). (2020). FAQs on ECB supervisory measures in reaction to the coronavirus.

Fan, V.F., Jamison, D.T., and Summers, L.H. (2018). Pandemic risk: How large are the expected losses. Bull World Health Organ 96.129-134.

Office of the Comptroller of the Currency (OCC), and Federal Deposit Insurance Corporation (FDIC). (2020). Regulatory capital rule: Eligible retained income rules and regulations, Federal Register Vol. 85, No. 55.

Office of the Superintendent of Financial Institutions (OFSI). (2020). OSFI actions to address operational issues stemming from COVID-19.

Onali, E. (2020). COVID-19 and stock market volatility. Available at SSRN 3571453.

Shahzad, S.J.H., Bouri, E., Roubaud, D., Kristoufek, L., Lucey, B. (2019). Is Bitcoin a better safe-haven investment than gold and commodities? International Review of Financial Analysis 63, 322-330.

World Economic Outlook (WEO). (2020). The great lockdown. World Economic Outlook reports. International Monetary Fund. Available at https://www.imf.org/en/Publications/WEO/Issues/2020/04/14/weo-april-2020

World Health Organization (WHO). (2019). A world at risk: Annual report on global preparedness for health emergencies. Available at https://apps.who.int/gpmb/assets/annual_report/GPMB_annualreport_2019.pdf.

World Health Organization (WHO). (2020). WHO Timeline - COVID-19. Available at https://www.who.int/news-room/detail/27-04-2020-who-timeline---covid-19.

Yarovaya, L., Matkovskyy, R., and Jalan, A. (2020). The effects of 'Black Swan' event (COVID-19) on herding behavior in cryptocurrency markets: Evidence from cryptocurrency USD, EUR, JPY and KRW markets. Available at SSRN 3586511. 


\section{Figures}
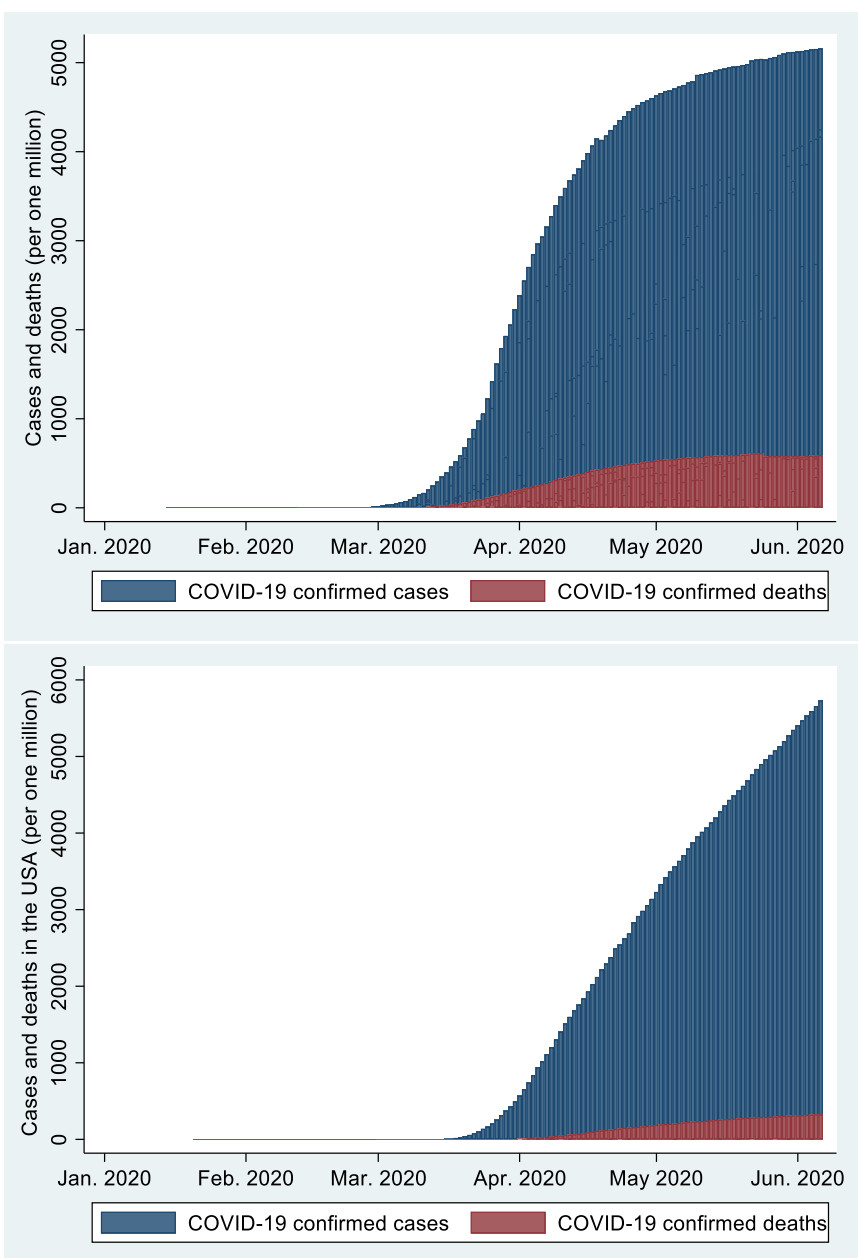

Fig 1B. The number of COVID-19 confirmed cases and death per one million in China. Source: Our World in Data website.

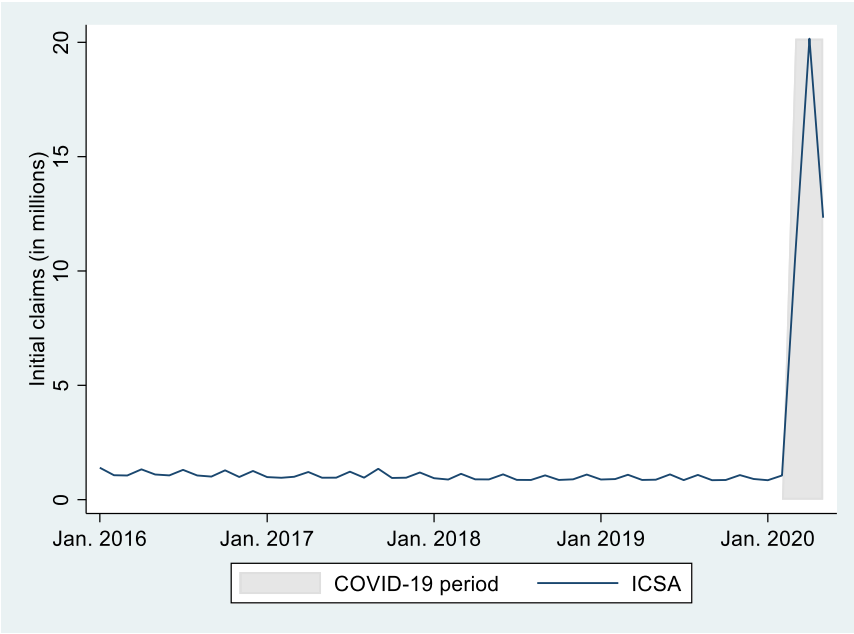

Fig 2A. Unemployment initial claims because of the COVID19 pandemic. This graph plots the unemployment initial claims in the United States and Canada resulting from the COVID19 pandemic. ICSA is the Initial Claims Seasonally Adjusted in the United States. The data is obtained at monthly frequency for January 2016 - May 2020. The grey shaded area represents the COVID-19 period, starting from March 1, 2020 and still ongoing. Source: the Federal Reserve Economic Data and Statistics Canada.
Fig 1A. The number of COVID-19 confirmed cases and deaths per one million in countries with Globally Systemically Important Banks (GSIBs). These countries include Canada, France, Germany, Italy, Japan, Netherlands, Spain, Sweden, Switzerland, and the UK. Source: Our World in Data website.

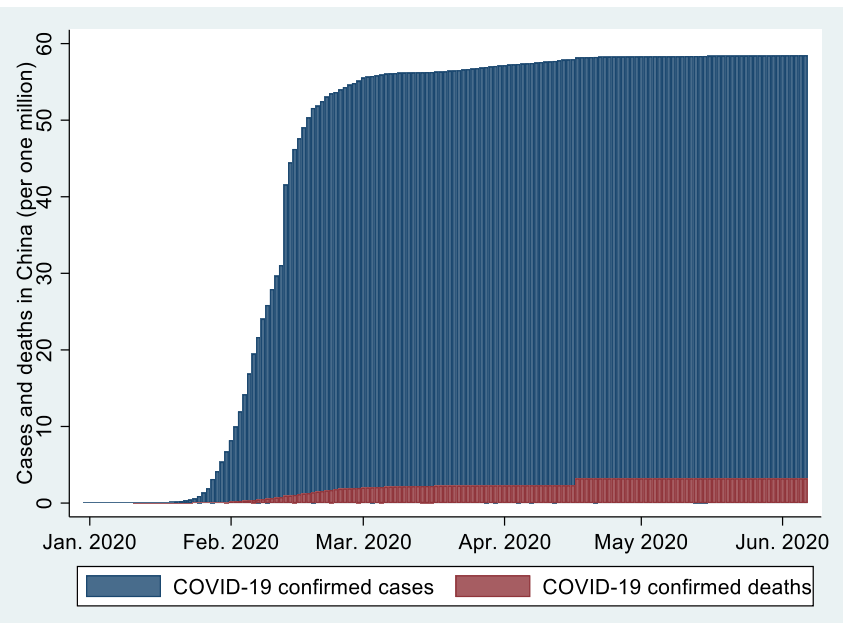

Fig 1C. The number of COVID-19 confirmed cases and death per one million in China. Source: Our World in Data website.

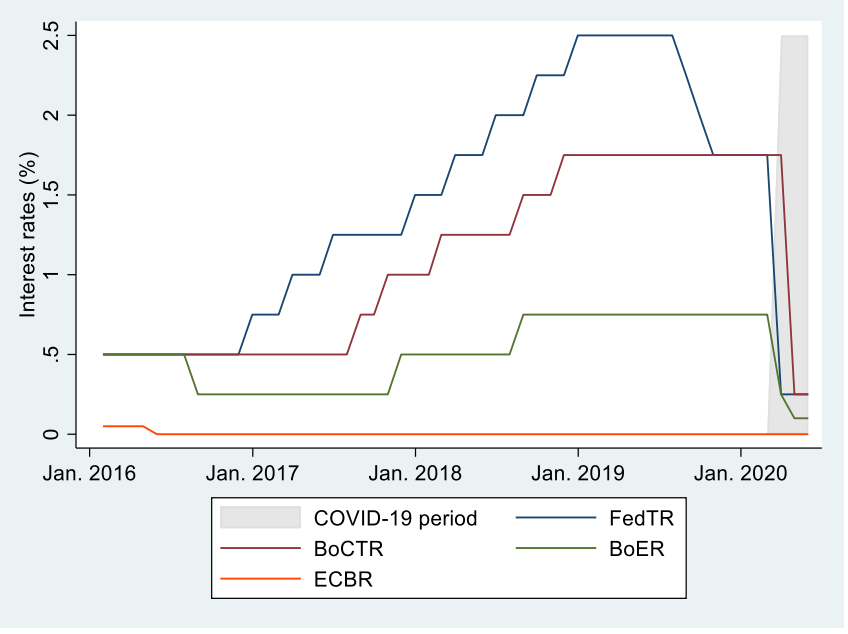

Fig 2B. Base interest rates as a response to COVID19 pandemic. This graph plots the trends in countries' base interest rates as a response to COVID19 pandemic. FedFR is the Federal Reserve Funds Rate. BoCTR is the Bank of Canada Target Rate. BOEBR is the Bank of England's Bank Rate. ECBRR is the European Central Bank's refinancing Rate. Source: the Federal Reserve Economic Data, Bank of Canada, Bank of England, and the European Central Bank. The data is obtained for January 2016 - May 2020. The grey shaded area represents the COVID-19 period, starting from March 1, 2020 and still ongoing. 

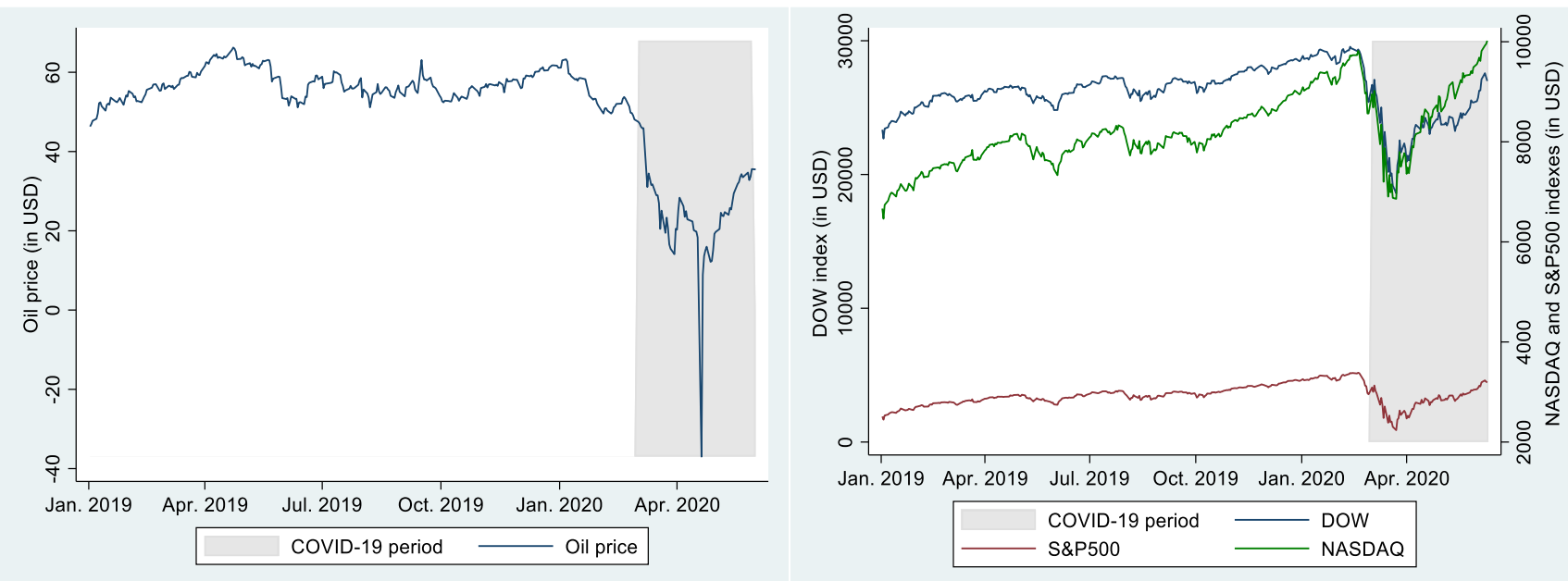

Fig 3A. This figure plots the West Texas Intermediate Crude oil price (Oil). Fig 3B. This figure plots price for the following security indexes: Dow The data is obtained at daily frequency for January 2, 2019 - June 5, 2020. Jones Industrial Average (Dow), S\&P500 (SP500), and NASDAQ. The data The grey shaded area represents the COVID-19 period, starting from March is obtained at daily frequency for January 2, 2019- June 5, 2020. The grey 1, 2020 and still ongoing. Source: Federal Reserve Economic Data. shaded area represents the COVID-19 period, starting from March 1, 2020 and still ongoing. Source: Yahoo Finance.
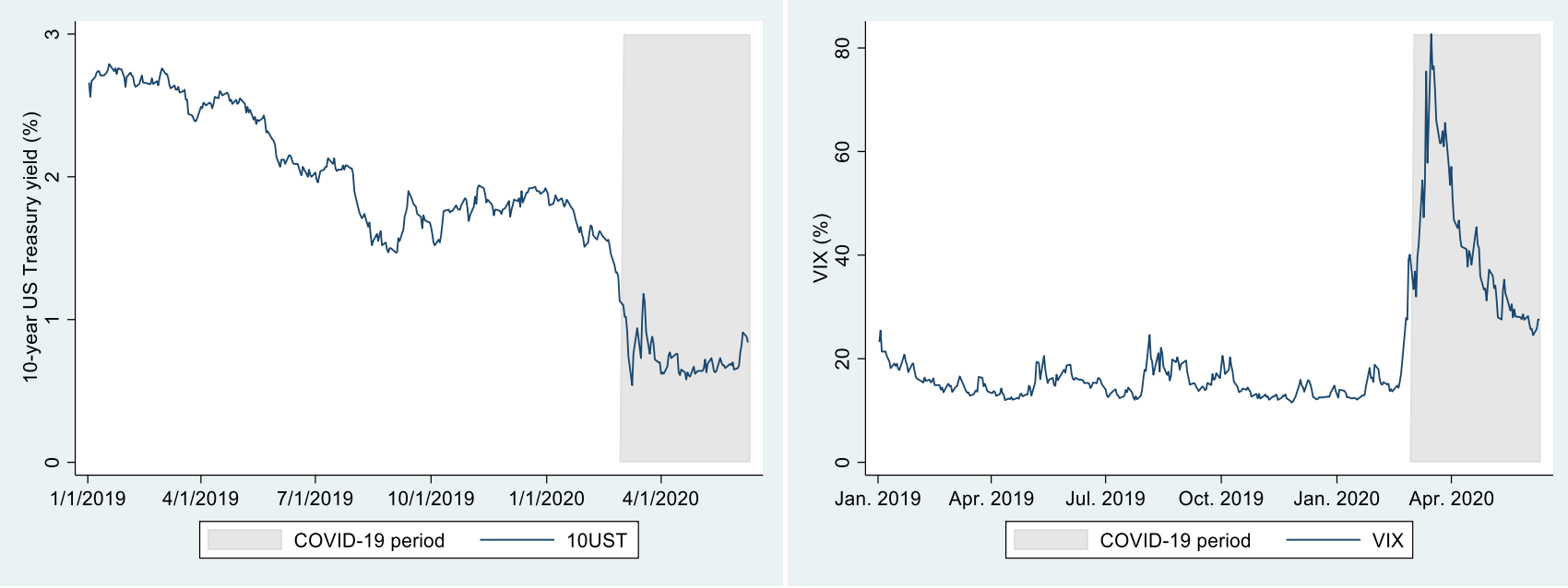

Fig 3C. This figure plots the 10-year Treasury bond index (10UST). The Fig 3D. This figure plots the Chicago Board Options Exchange's CBOE data is obtained at daily frequency for January 2,2019 - June 5, 2020. The Volatility Index (VIX). The data is obtained at daily frequency for January grey shaded area represents the COVID-19 period, starting from March 1, 2, 2019 - June 5, 2020. The grey shaded area represents the COVID-19 2020 and still ongoing. Source: Federal Reserve Economic Data. period, starting from March 1, 2020 and still ongoing. Source: Federal Reserve Economic Data. 

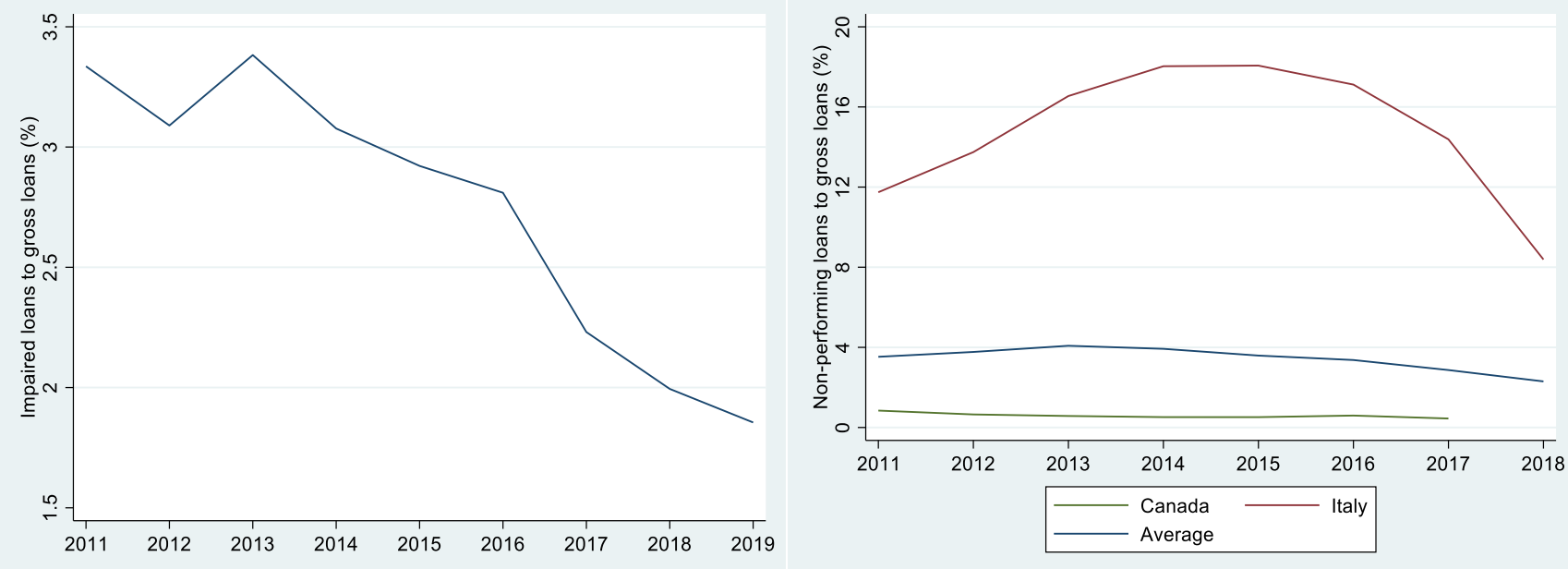

Fig 4A. This figure plots the ratio of impaired loans to gross loans. The data Fig 4B. This figure plots the ratio of impaired loans to gross loans. The data is obtained at yearly frequency for $2011-2019$. Source: Orbis BankFocus. is obtained at yearly frequency for $2011-2019$. Source: Orbis BankFocus.
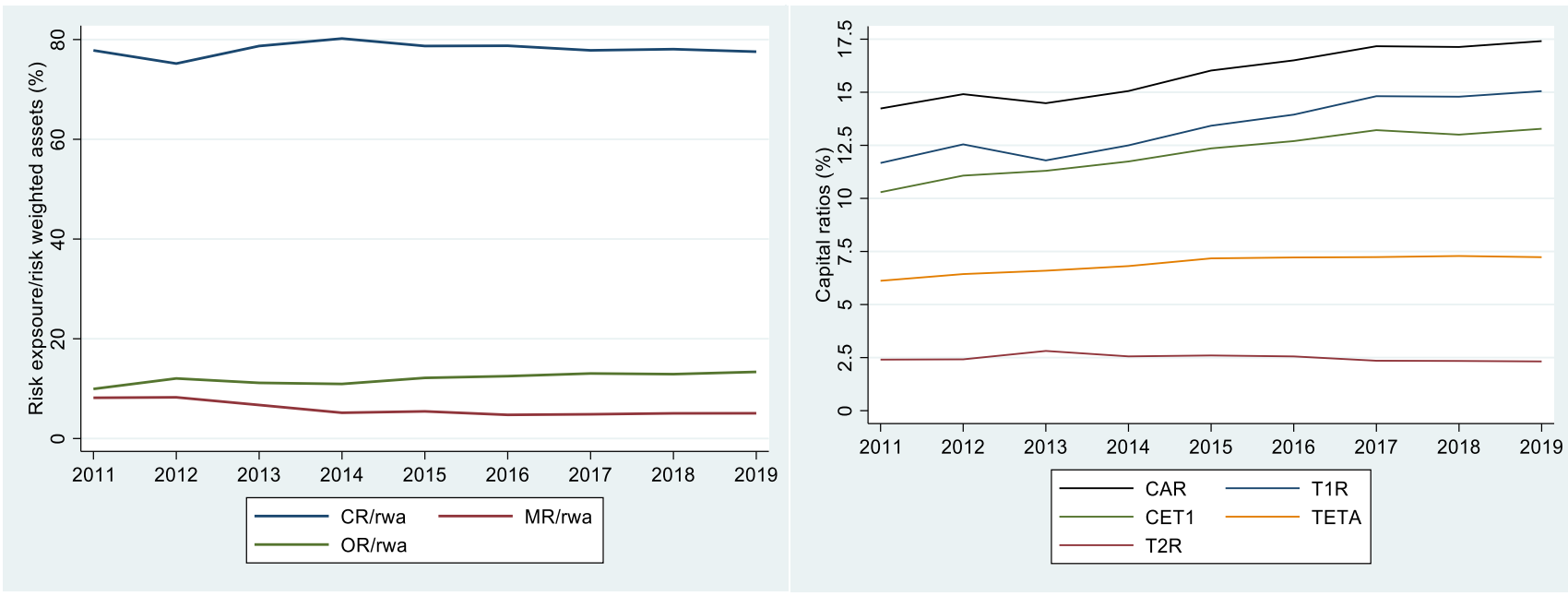

Fig 4C. This figure plots the ratio of bank risk exposure to risk-weighted Fig 4D. This graph plots G-SIBs compliance with Basel III capital ratios. assets. $\mathrm{CR} / \mathrm{rwa}$ is the risk-weighted assets dedicated to credit risk divided CAR is the bank capital adequacy ratio defined as Tier 1 capital plus Tier 2 by total risk-weighted assets. MR/rwa is the risk-weighted assets dedicated capital divided by risk-weighted assets. T1R is the Tier 1 capital divided by to market risk divided by total risk-weighted assets. OR/rwa is the risk- risk-weighted assets. T2R is Tier 2 capital divided by risk-weighted assets. weighted assets dedicated to operational risk divided by total risk-weighted CET1 is core capital divided by risk-weighted assets. TETA is the total assets. The data is obtained at yearly frequency for $2011-2019$. Source: Orbis BankFocus.

equity to total assets (unweighted) ratio. The data is obtained at yearly frequency for $2011-2019$. Source: Orbis BankFocus.

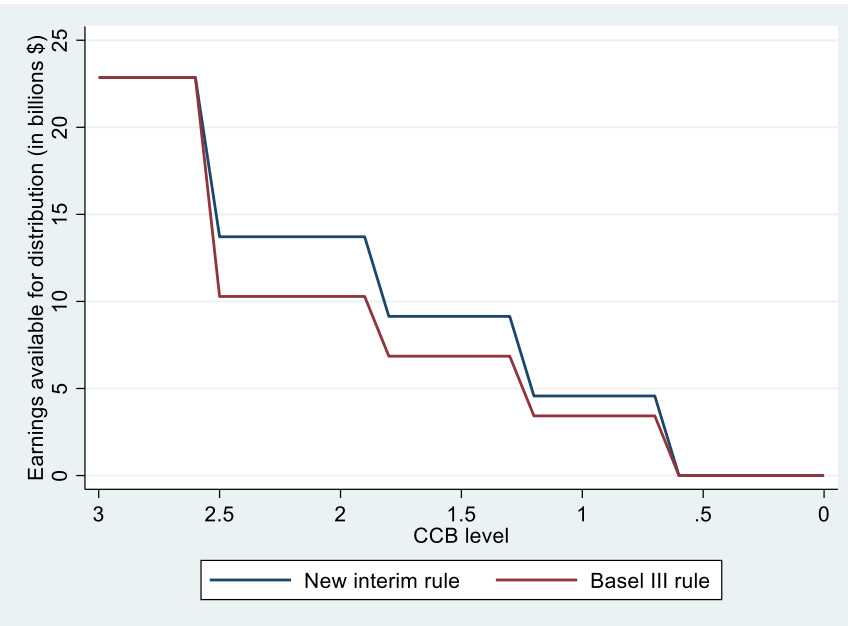

Fig 5. This figure compares the maximum payout amounts under the new COVID-19 interim rule and the Basel III rule in the US. The data required on earnings to compute the maximum payout amounts for quarter 4, 2019 is obtained at quarterly frequency for quarter 3, 2018 to quarter 3, 2019. The sample used includes five G-SIBs. Source: CRSP/Compustat merged database. 
Tables

Table 1

G-SIBs aggregated balance sheet's components (in thousands \$), end of 2017

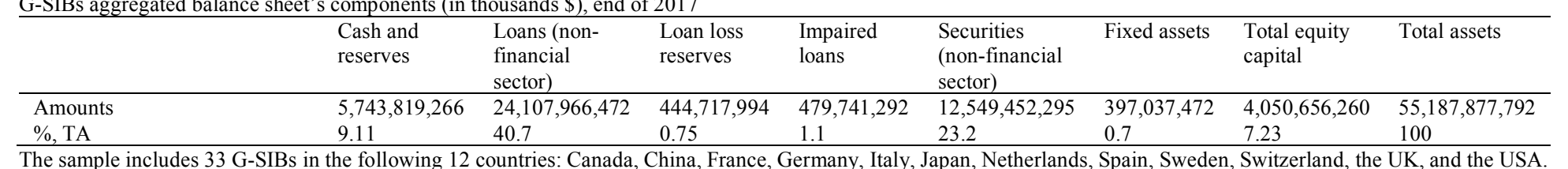

Table 2

Basel III capital reforms in the PreCOVID-19 period using a sample of Globally Systemically Important Banks (G-SIBs)

\begin{tabular}{|c|c|c|c|c|c|c|c|c|c|c|c|}
\hline \multirow[t]{2}{*}{ Country } & \multicolumn{4}{|c|}{ National and international regulatory capital ratios } & \multicolumn{2}{|c|}{$\begin{array}{l}\text { Additional } \\
\text { buffers }\end{array}$} & \multicolumn{2}{|c|}{ Treatment for G-SIBs } & \multirow{2}{*}{\multicolumn{2}{|c|}{$\begin{array}{l}\text { National authorities' capital } \\
\text { requirements } \\
\text { CAR+CCB+CyB+G-SIBs } \\
\text { capital surcharge }\end{array}$}} & \multirow{2}{*}{$\begin{array}{l}\text { Actual CAR (as } \\
\text { reported by G-SIBs) } \\
\text { (Tier1+Tier2)/RWA }\end{array}$} \\
\hline & $\begin{array}{l}\text { \# G- } \\
\text { SIBs }\end{array}$ & $\begin{array}{l}\text { Prudential } \\
\text { regulators }\end{array}$ & $\begin{array}{l}\text { Yearly } \\
\text { update }\end{array}$ & $\begin{array}{l}\text { Minimum } \\
\text { CAR (\%) }\end{array}$ & $\begin{array}{l}\text { CCB } \\
(\%)\end{array}$ & $\begin{array}{l}\text { CyB } \\
(\%)\end{array}$ & $\begin{array}{l}\text { G-SIBs } \\
\text { bucket }\end{array}$ & $\begin{array}{l}\text { G-SIBs capital } \\
\text { surcharge }(\%)\end{array}$ & & & \\
\hline Canada & 2 & OSFI and BIS & 2019 & 8 & 2.5 & 2.25 & 1 ( 2 bank $)$ & 1 & \multicolumn{2}{|c|}{$13.25 \%$} & $14.78 \%$ \\
\hline China & 4 & CBRC and BIS & 2019 & 8 & 2.5 & 2.5 & $\begin{array}{l}1 \text { ( } 2 \text { banks }) \\
2 \text { ( } 2 \text { banks })\end{array}$ & $\begin{array}{c}1 \\
1.5\end{array}$ & \multicolumn{2}{|c|}{ Between $13.5 \%$ and $14 \%$} & $14.03 \%$ \\
\hline France & 4 & ESRB and BIS & 2020 & 8 & 2.5 & 0.5 & $\begin{array}{l}1 \text { (3 banks) } \\
2 \text { (1 banks) }\end{array}$ & $\begin{array}{c}1 \\
1.5\end{array}$ & \multicolumn{2}{|c|}{ Between $12 \%$ and $12.5 \%$} & $15.64 \%$ \\
\hline Germany & 1 & ESRB and BIS & 2016 & 8 & 2.5 & 0 & 2 (1 bank) & 1.5 & \multicolumn{2}{|c|}{$12 \%$} & $16.3 \%$ \\
\hline Japan & 3 & FSA and BIS & 2016 & 8 & 2.5 & 0 & $\begin{array}{l}1 \text { ( } 2 \text { banks }) \\
2 \text { (1 banks) }\end{array}$ & $\begin{array}{c}1 \\
1.5\end{array}$ & \multicolumn{2}{|c|}{ Between $13.5 \%$ and $14 \%$} & $16.26 \%$ \\
\hline Netherlands & 1 & ESRB and BIS & 2016 & 8 & 2.5 & 0 & 1 (1 bank) & 1 & & & $16.72 \%$ \\
\hline Spain & $2^{*}$ & ESRB and BIS & 2016 & 8 & 2.5 & 0 & 1 ( 2 banks $)$ & 1 & & & $13.91 \%$ \\
\hline Sweden & $1^{*}$ & ESRB and BIS & 2020 & 8 & 2.5 & 2.5 & 1 (1 bank) & 1 & & & $19.16 \%$ \\
\hline Switzerland & 2 & BIS & 2020 & 8 & 2.5 & 0 & 1 ( 2 banks $)$ & 1 & & & $18.14 \%$ \\
\hline \multirow[t]{3}{*}{ UK } & $4^{*}$ & FPC and BIS & 2020 & 8 & 2.5 & 1 to & 1 ( 2 banks $)$ & 1 & \multirow{3}{*}{\multicolumn{2}{|c|}{ Between $11.5 \%$ and $12.5 \%$}} & \\
\hline & & & & & & 0 & 2 (1 bank) & 1.5 & & & $17.88 \%$ \\
\hline & 8 & Fed and BIS & 2016 & 8 & 2.5 & 0 & $\begin{array}{l}3 \text { (1 bank) } \\
1 \text { (3 banks) }\end{array}$ & $\begin{array}{l}2 \\
1\end{array}$ & \multirow{2}{*}{\multicolumn{2}{|c|}{ Between $11.5 \%$ and $13 \%$}} & \\
\hline USA & & & & & & & 4 (1 bank) & 2.5 & & & \\
\hline \multicolumn{12}{|c|}{ Panel B. Components of bank regulatory capital (in thousands \$) } \\
\hline & \# G-S & S Year & CET1 capital & $\begin{array}{l}\text { Additional } \\
\text { Tier } 1 \text { capital }\end{array}$ & Tier & capital & Tier 2 capital & $\begin{array}{l}\text { Capital } \\
\text { adequacy }\end{array}$ & $\mathrm{CCB}$ & CyB & $\begin{array}{l}\text { G-SIBs capital } \\
\text { surcharge }\end{array}$ \\
\hline Canada & 1 & 2016 & $40,818,473$ & $1,742,893$ & 42,5 & 1,366 & $7,007,386$ & $49,568,752$ & $8,388,303$ & $7,549,473$ & $3,355,321$ \\
\hline China & 4 & 2017 & $985,545,922$ & $52,928,311$ & 1,03 & ,474,233 & $169,718,498$ & $1,208,192,731$ & $205,733,584$ & $205,733,584$ & $103,840,150$ \\
\hline France & 4 & 2017 & $303,945,687$ & $29,115,396$ & 333 & 61,083 & $58,499,435$ & $391,560,518$ & $57,062,981$ & $11,412,596$ & $26,675,349$ \\
\hline Germany & 1 & 2017 & $60,934,013$ & $8,182,821$ & 69,1 & 6,834 & $7,656,328$ & $76,773,162$ & $10,320,489$ & 0 & $6,192,294$ \\
\hline Netherlands & 1 & 2017 & $48,693,961$ & $5,534,768$ & 54,2 & 8,729 & $13,242,666$ & $67,471,395$ & $9,273,191$ & 0 & $3,709,277$ \\
\hline Spain & 2 & 2017 & $139,735,191$ & $9,293,372$ & 149 & 28,563 & $26,649,636$ & $175,678,199$ & $28,985,578$ & 0 & $11,594,232$ \\
\hline Sweden & 1 & 2017 & $29,400,829$ & $4,189,153$ & 33,5 & 9,982 & $4,484,181$ & $38,074,163$ & $3,771,180$ & $3,771,180$ & $1,508,472$ \\
\hline Switzerland & 1 & 2017 & $36,974,000$ & $2,432,000$ & 39,4 & 6,000 & $8,077,000$ & $47,483,000$ & $6,089,920$ & 0 & $2,435,968$ \\
\hline UK & 4 & 2017 & $263,645,288$ & $58,459,048$ & 322 & 04,336 & $74,562,195$ & $396,666,531$ & $46,137,441$ & $18,454,976$ & $29,283,252$ \\
\hline USA & 8 & 2017 & $817,550,200$ & $109,768,750$ & 927 & 18,950 & $129,374,284$ & $1,056,693,234$ & $158,217,953$ & 0 & $112,116,734$ \\
\hline All & 27 & 2017 & $2,727,243,564$ & $281,646,512$ & 3,00 & 890,076 & $499,271,609$ & $3,508,161,685$ & $533,980,620$ & $247,760,639$ & $300,711,049$ \\
\hline
\end{tabular}

${ }^{\dagger}$ OSFI is the Canadian Office of the Superintendent of Financial institutions. CBRC is the Chinese Banking Regulation Commission. ESRB is the European Systemic Risk Board. FSA is the Japanese Financial Services Agency. FPC is the UK's Financial Policy Committee. Fed is the Federal Reserve. BIS is the Bank for International Settlements. G-SIBs is Globally Systemically Important Banks. CET1 is Common Equity Tier 1. CCB is Capital Conservation Buffer. CyB is the Countercyclical Buffer.

*Only one of the two largest Spanish banks, Santander Bank, is still considered as a G-SIB in the BIS 2019 list. Nordea bank in Sweden and Royal Bank of Scotland in the UK were considered as G-SIBs until 2017. In Panel B, We exclude Italy and Japan because of missing data on some regulatory capital components. 
Table 3

Governments' responses to COVID-19 pandemic

\begin{tabular}{|c|c|c|c|c|c|c|}
\hline & \multirow{2}{*}{$\begin{array}{l}\text { Prudential } \\
\text { regulator }\end{array}$} & \multicolumn{3}{|l|}{ G-SIBs - Capital measures } & \multirow{2}{*}{$\begin{array}{l}\text { Economic actions } \\
\text { Stimulus packages and changes in the } \\
\text { monetary policy }\end{array}$} & \multirow[t]{2}{*}{ Potential implications } \\
\hline & & Capital adequacy & $\begin{array}{l}\text { Capital buffers (i.e. CCB, CyB, and G- } \\
\text { SIBs capital surcharge) }\end{array}$ & Loan Loss Reserves & & \\
\hline USA & $\begin{array}{l}\text { FDIC and } \\
\text { OCC } \\
\text { (March 20, } \\
2020)\end{array}$ & $\begin{array}{l}\text { The Fed, the FDIC, and the } \\
\text { OCC support banks that } \\
\text { choose to use their capital } \\
\text { buffers to lend and undertake } \\
\text { other supportive actions } \\
\text { during the COVID-19 period. }\end{array}$ & $\begin{array}{l}\text { - If G-SIBs' CCB falls below } 2.5 \% \text { of } \\
\text { risk-weighted assets plus the } \\
\text { required CyB and the G-SIBs capital } \\
\text { surcharge, they become subject to } \\
\text { limitations on capital distributions. } \\
\text { - Distribution limitations under the } \\
\text { CCB are calculated as a percentage } \\
\text { of eligible retained income. Eligible } \\
\text { retained income is defined as the } \\
\text { average net income for the four } \\
\text { calendar quarters preceding the } \\
\text { current calendar quarter, net of any } \\
\text { distributions. } \\
\text { - The new revised rule of eligible } \\
\text { retained income is the average net } \\
\text { income for the } 4 \text { calendar quarters } \\
\text { preceding the current calendar } \\
\text { quarter without deducting } \\
\text { distributions. } \\
\text { - The revised rule allows G-SIBs to } \\
\text { follow a more gradually limit } \\
\text { distributions on capital in the } \\
\text { COVID-19 period. }\end{array}$ & No changes & $\begin{array}{l}\text { Introduce a } \$ 2,142 \text { billion emergency } \\
\text { stimulus bill. The bill includes direct and } \\
\text { indirect financial aid to households, } \\
\text { businesses, banks, and personal finance and } \\
\text { taxes. The stimulus bill is distributed on the } \\
\text { following key sectors: } \\
\text { - } \$ 300 \text { billion in direct payment to } \\
\text { households, providing } \$ 1,200 \text { to adults } \\
\text { and } \$ 500 \text { per child. } \\
\text { - } \$ 250 \text { billion to make unemployment } \\
\text { insurance available to a larger category of } \\
\text { workers and extends the duration of the } \\
\text { benefits from } 26 \text { weeks to } 39 \text { weeks. } \\
\text { - } \$ 349 \text { billion in loans to small businesses, } \\
\text { covering payroll, rent, and utilities. } \\
\text { - } \$ 500 \text { billion to expand the Fed lending } \\
\text { facilities and guarantee loans. } \\
\text { - } \$ 32 \text { billion in grants to cover airlines } \\
\text { companies and contractors. } \\
\text { - } \$ 150 \text { billion in direct aid to states, } \\
\text { distributed according to population size. } \\
\text { - } \$ 221 \text { billion in tax benefits for businesses } \\
\text { allowing them to defer payroll taxes for } \\
\text { the rest of the year. } \\
\text { - } \$ 340 \text { billion in additional spending to } \\
\text { hospitals and public transit. }\end{array}$ & $\begin{array}{l}\text { The key outcome of the stimulus } \\
\text { package as well as Fed interest } \\
\text { cuts is to secure funds to } \\
\text { unemployed workers, households } \\
\text { and affected businesses. Along } \\
\text { with easing capital measures, } \\
\text { these urgent governmental } \\
\text { intervention policies allow } \\
\text { various stakeholders to continue } \\
\text { their lending and borrowing } \\
\text { activities without significantly } \\
\text { affecting economic growth. }\end{array}$ \\
\hline $\mathrm{EU}$ & $\begin{array}{l}\text { ECB } \\
\text { (March 12, } \\
\text { 2020; April } \\
3,2020)\end{array}$ & $\begin{array}{l}\text { The ECB will allow banks to } \\
\text { operate temporarily below the } \\
\text { level of Pillar } 2 \text { Guidance } \\
\text { (P2G), the CCB, the CyB, and } \\
\text { the G-SIBs capital surcharge. } \\
\text { Banks are allowed to } \\
\text { temporarily use instruments } \\
\text { that do not qualify as CET1 in } \\
\text { meeting their minimum } \\
\text { capital requirements. } \\
\text { Banks with capital buffers } \\
\text { that fall below the minimum } \\
\text { capital requirements can still } \\
\text { distribute profits. }\end{array}$ & $\begin{array}{l}\text { The ECB is allowing banks to release } \\
\text { their CCBs as well as their CyBs. } \\
\text { However, EU countries have different } \\
\text { requirements in term of their CyBs. } \\
\text { Banks in countries such as Germany, } \\
\text { Italy, Netherlands, and Spain have no } \\
\text { CyBs requirements while banks in } \\
\text { France and Sweden are required to } \\
\text { maintain } 0.5 \% \text { and } 2.5 \% \text { of risk- } \\
\text { weighted assets, respectively. Thus, } \\
\text { releasing CyBs may not have the same } \\
\text { effect on stimulating economic growth, } \\
\text { as some countries did not accumulate } \\
\text { additional capital to build up their } \\
\text { CyBs. }\end{array}$ & $\begin{array}{l}\text { ECB will exercise flexibility } \\
\text { regarding the classification of } \\
\text { borrowers as "unlikely to pay". } \\
\text { Loans that become non- } \\
\text { performing will receive a } \\
\text { preferential prudential treatment } \\
\text { from supervisors about loss } \\
\text { provisioning. } \\
\text { ECB will exercise flexibility in } \\
\text { the implementation of banks non- } \\
\text { performing loans (NPLs) } \\
\text { reduction strategies. }\end{array}$ & $\begin{array}{l}\text { The Fed cuts the federal fund rate to } 0.25 \% \text {. } \\
\text { EU member states are committed to provide } \\
\text { liquidity support for various sectors in } \\
\text { distress. This support is estimated at } 16 \% \text { of } \\
\text { EU GDP. It consists of public guarantee } \\
\text { schemes and deferred tax payments. } \\
\text { - Introduce a Coronavirus Investment } \\
\text { Initiative allowing EU countries to use } \\
€ 37 \text { billion to address the consequences } \\
\text { related to the COVID- } 19 \text { crisis. } \\
\text { - Introduce a } € 750 \text { billion Pandemic } \\
\text { Emergency Purchase Programme (PEPP) } \\
\text { that aims to purchase private and public } \\
\text { securities with maturity date ranging } \\
\text { between } 70 \text { days and } 30 \text { years. }\end{array}$ & $\begin{array}{l}\text { Provide more flexibility to EU } \\
\text { banks in addressing current } \\
\text { economic conditions while } \\
\text { ensuring the resiliency of the } \\
\text { financial system. }\end{array}$ \\
\hline
\end{tabular}

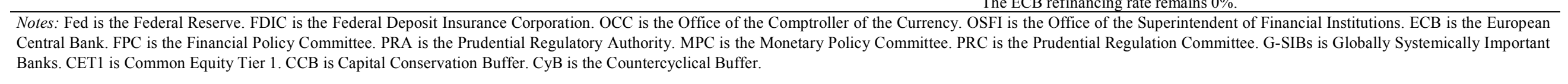


Table 3

Governments' responses to COVID-19 pandemic - (continued)

\begin{tabular}{|c|c|c|c|c|c|c|}
\hline & \multirow{2}{*}{$\begin{array}{l}\text { Prudential } \\
\text { regulator }\end{array}$} & \multicolumn{3}{|l|}{ G-SIBS - Capital measures } & \multirow{2}{*}{$\begin{array}{l}\text { Macroeconomic actions } \\
\text { Stimulus packages and changes in the } \\
\text { monetary policy }\end{array}$} & \multirow{2}{*}{ Potential implications } \\
\hline & & Capital adequacy & $\begin{array}{l}\text { Capital buffers (i.e. CCB, CyB, and G- } \\
\text { SIBs capital surcharge) }\end{array}$ & Loan Loss Reserves & & \\
\hline UK & $\begin{array}{l}\text { FPC, MPC, } \\
\text { and PRC } \\
\text { (March 24, } \\
2020 \text { ) and } \\
\text { Bank of } \\
\text { England } \\
\text { (March 11, } \\
2020 \text { ) }\end{array}$ & $\begin{array}{l}\text { Bank capital buffers can be } \\
\text { drawn down as much as } \\
\text { necessary to support the } \\
\text { economy through the } \\
\text { COVID-19 temporary shock. }\end{array}$ & $\begin{array}{l}\text { Reduce the CyB from } 1 \% \text { to } 0 \% \text {. This } \\
\text { measure will stand for } 12 \text { months. } \\
\text { This reduction will provide } £ 190 \text { in } \\
\text { support to businesses and individuals. } \\
\text { PRA estimates that the release of the } \\
\text { CyB is equivalent to } 13 \text { times bank net } \\
\text { lending to businesses in } 2019 \text {. } \\
\text { Banks should not use CyB and other } \\
\text { facilities in terms of easing capital } \\
\text { requirements to increase dividends and } \\
\text { bonuses. }\end{array}$ & $\begin{array}{l}\text { The PRA will exercise more } \\
\text { flexibility regarding the use of } \\
\text { forward-looking measures as the } \\
\text { one required in the IFRS9. PRA } \\
\text { reminds banks to be both } \\
\text { reasonable and supportable in } \\
\text { incorporating the impact of } \\
\text { Covid-19 on borrowers into the } \\
\text { expected credit loss (ECL) model. } \\
\text { The relief measures taken by the } \\
\text { government enable bank } \\
\text { borrowers to continue their } \\
\text { regulator payments even if loans } \\
\text { are deferred in the short-run. }\end{array}$ & $\begin{array}{l}\text { Introduce a new Term Funding Scheme for } \\
\text { Small and Medium-sized Enterprises } \\
\text { (TSFME) to provide support up to } £ 100 \\
\text { billion to bridge credit supply issues. } \\
\text { TSFME will be available for } 12 \text { months and } \\
\text { offers } 4 \text { years funding with interest rates } \\
\text { very close to the bank rate. } \\
\text { Banks can borrow around } £ 300 \text { billion in } \\
\text { from the Bank of England in all major } \\
\text { currencies and on weekly basis. } \\
\text { Bank of England cuts base rate to } 0.1 \% \text {. }\end{array}$ & $\begin{array}{l}\text { These actions should allow } \\
\text { banks with the capacity to } \\
\text { supplying credit to the UK } \\
\text { economy. Particularly, they } \\
\text { provide insurance against } \\
\text { adverse conditions in bank } \\
\text { funding markets while at the } \\
\text { same time incentivize banks to } \\
\text { secure credit to businesses and } \\
\text { households. }\end{array}$ \\
\hline Canada & $\begin{array}{l}\text { OSFI } \\
\text { (March 27, } \\
2020)\end{array}$ & $\begin{array}{l}\text { OSFI delayed the } \\
\text { implantation of the Basel III } \\
\text { guidelines on standardized } \\
\text { approach and internal rating } \\
\text { based approach to credit risk } \\
\text { and operational risk to } 2023 \text {. } \\
\text { OSFI delayed the } \\
\text { implantation of the Basel III } \\
\text { guidelines on leverage ratio to } \\
2023 \text {. }\end{array}$ & $\begin{array}{l}\text { OSFI lowered the CyB from } 2.25 \% \text { to } \\
1 \% \text {. This action will allow largest } \\
\text { Canadian banks to increase their } \\
\text { lending capacities by } \$ 300 \text { billion. }\end{array}$ & $\begin{array}{l}\text { Banks will treat mortgage } \\
\text { payment deferrals as performing } \\
\text { loans to avoid increases in } \\
\text { RWAs. Loan payments can be } \\
\text { deferred for a period of } 6 \text { months. }\end{array}$ & $\begin{array}{l}\text { Introduce a } \$ 107 \text { billion economic response } \\
\text { plan. The plan provides support to } \\
\text { households, small businesses, and large } \\
\text { corporations. The economic response plan is } \\
\text { distributed on the following key sectors: } \\
\text { - } \$ 52 \text { billion to households and businesses. } \\
\text { - } \$ 55 \text { billion in tax benefits, allowing } \\
\text { individuals and businesses to defer payroll } \\
\text { taxes until June } 1,2020 \text { for individuals } \\
\text { and August } 31,2020 \text { for corporations. } \\
\text { - } 75 \% \text { wage subsidy is available to small } \\
\text { and medium businesses for a period of } \\
\text { three months starting on March } 15,2020 \text {. } \\
\text { Introduce the Canada Emergency Response } \\
\text { Benefit (CERB) providing a } \$ 2000 \text { in direct } \\
\text { support for } 4 \text { months starting on March } 15 \text {, } \\
2020 \text {. This support is available for people } \\
\text { who lost their job because of Covid- } 19 \text {. } \\
\text { Bank of Canada cuts target rate to } 0.25 \%\end{array}$ & $\begin{array}{l}\text { Provide more flexibility to banks } \\
\text { in addressing current economic } \\
\text { conditions while ensuring } \\
\text { financial stability. } \\
\text { Reduce unemployment rate. } \\
\text { Maintain the funding channels } \\
\text { between banks and the real } \\
\text { economic and avoid economic } \\
\text { recession. }\end{array}$ \\
\hline
\end{tabular}

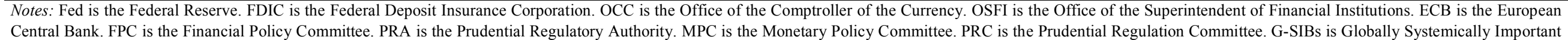
Banks. CET1 is Common Equity Tier 1. CCB is Capital Conservation Buffer. CyB is the Countercyclical Buffer.
} 